\section{OPEN ACCESS}

Edited by:

Anouschka R. Hof

Wageningen University, Research,

Netherlands

Reviewed by:

Pierre L. Ibisch,

Eberswalde University for Sustainable

Development, Germany

M. Isabel Martínez-Nieto,

University of Valencia, Spain

*Correspondence:

Jalil Noroozi

jalil.noroozi@univie.ac.at

Specialty section:

This article was submitted to Biogeography and Macroecology,

a section of the journal

Frontiers in Ecology and Evolution

Received: 19 December 2018

Accepted: 23 April 2019

Published: 14 May 2019

Citation:

Noroozi J, Zare G, Sherafati M, Mahmoodi M, Moser D, Asgarpour Z and Schneeweiss GM (2019) Patterns

of Endemism in Turkey, the Meeting

Point of Three Global Biodiversity

Hotspots, Based on Three Diverse

Families of Vascular Plants.

Front. Ecol. Evol. 7:159.

doi: 10.3389/fevo.2019.00159

\title{
Patterns of Endemism in Turkey, the Meeting Point of Three Global Biodiversity Hotspots, Based on Three Diverse Families of Vascular Plants
}

\section{Jalil Noroozi ${ }^{1 *}$, Golshan Zare ${ }^{2}$, Mahbubeh Sherafati ${ }^{3}$, Mohammad Mahmoodi ${ }^{4}$, Dietmar Moser ${ }^{1}$, Zahra Asgarpour ${ }^{1}$ and Gerald M. Schneeweiss ${ }^{1}$}

\begin{abstract}
'Department of Botany and Biodiversity Research, University of Vienna, Vienna, Austria, ${ }^{2}$ Department of Pharmaceutical Botany, Faculty of Pharmacy, Hacettepe University, Ankara, Turkey, ${ }^{3}$ Department of Plant Biology, Faculty of Biological Sciences, Tarbiat Modares University, Tehran, Iran, ${ }^{4}$ Botany Research Division, Research Institute of Forests and Rangelands, Agricultural Research, Education and Extension Organization, Tehran, Iran
\end{abstract}

Centers of endemism and areas of endemism are important biogeographic concepts with high relevance for conservation and evolutionary biology. Turkey is located at the intersection of three global biodiversity hotspots (Mediterranean, Caucasian, Irano-Anatolian) and harbors remarkable levels of plant diversity and endemism. Nevertheless, hotspots of vascular plant endemics have never been identified using formal quantitative approaches in this diverse region. Here, using data on 1,102 endemic taxa of three species-rich families (Asteraceae, Lamiaceae, Boraginaceae) we identified (i) centers of endemism based on three well-established indices (endemic richness, range-restricted endemic richness and weighted endemic richness) and (ii) areas of endemism using Endemicity Analysis. A total of 14 grid cells belonging to centers of endemism are identified as hotspots by at least one of the indices. Areas of endemism were identified in south-western Turkey (West-Taurus), southern and central Anatolia (Anatolian Diagonal), in north-eastern Turkey (Pontic-Ala), and in south-eastern Turkey (Hakkari). All hotspots of plant endemism in Turkey included high mountains, which are severely threatened by anthropogenic activities. Although the identified centers of endemism cover only $16 \%$ of surface area of Turkey they harbor $59 \%$ of the endemic taxa, emphasizing their conservation priority. As the majority of the endemic taxa of Turkey are local endemics and narrowly distributed, protection of the identified hotspots would allow a high proportion of likely threatened species to be protected.

Keywords: Anatolia, areas of endemism, biodiversity conservation, biodiversity hotspots, biogeography, centers of endemism 


\section{INTRODUCTION}

Endemism, i.e., the restriction of a taxon to a geographic place (irrespective of taxonomic and geographic scale), is one of the central concepts in biogeography (Anderson, 1994), which has been widely used to define floristic units (Rivas-Martínez et al., 1997). Centers of endemism (CEs) are areas with a high number of narrowly distributed species (endemism hotspots: Crisp et al., 2001). Ecologists are interested in those because of their importance in planning conservation priorities (Crosby, 1994; Ceballos et al., 1998; Myers et al., 2000; Linder, 2001; Jetz et al., 2004), which is helpful when funds for conservation are limited (Margules and Pressey, 2000; Myers et al., 2000; Brooks et al., 2006). On the other hand, areas of endemism (AEs) are fundamental entities of analyses in biogeography (Morrone, 2008). They are defined as areas that are not only rich in endemics, but whose species have congruent distributions (Morrone and Crisci, 1995; Linder, 2001; Bradshaw et al., 2015). Biogeographers and evolutionary biologists focus on explaining the causes for the occurrence of AEs (Nelson and Platnick, 1981; Major, 1988; Anderson, 1994). Although both CEs and AEs are very important in conservation biology, they are little investigated even in well-known global biodiversity hotspots.

A total of 34 global biodiversity hotspots are currently established as conservation priorities at a global scale (Myers et al., 2000; Mittermeier et al., 2005). These are characterized by an extraordinary richness of endemic species facing strong habitat loss (Myers et al., 2000). However, these hotspots are too coarse for conservation management, and identification of "hotspots-within-hotspots" (Cañadas et al., 2014) is necessary for a comprehensive protection management (Harris et al., 2005; Murray-Smith et al., 2009; Cañadas et al., 2014). As endemic species are well-suited to recognize biodiversity hotspots (Myers et al., 2000; Mittermeier et al., 2005; Orme et al., 2005; Possingham and Wilson, 2005) and because endemic richness of plants and vertebrates are correlated (Kier et al., 2009), identifying CEs and AEs based on plant endemics is very useful to determine such "hotspots-within-hotpots" for regional conservation management.

Turkey harbors remarkable bioclimatic and geomorphological diversity and supports very different vegetation types (Parolly, 2004). It is situated at the intersection of three biogeographical regions (Mediterranean, Euro-Siberian and Irano-Turanian regions; Davis, 1971; Takhtajan, 1986). Although Turkey does not cover any of the regions with globally highest Endemism Richness (Kier et al., 2009), it participates in three global biodiversity hotspots (Mediterranean, Caucasian and IranoAnatolian biodiversity hotspots; Mittermeier et al., 2005), which cover more than $80 \%$ of the surface area of this country (Figure 1). The flora comprises ca. 12,000 vascular plant taxa, of which about $32 \%$ are endemics (Güner et al., 2012). Several studies have focused on patterns of endemism, chorology and distribution of vascular plants in Turkey (Davis, 1971; Runemark,

Abbreviations: AE, Area of Endemism; CE, Center of Endemism; ER, Endemic Richness; RER, Range-restricted Endemic Richness; WER, Weighted Endemic Richness.
1971; Davis and Hedge, 1975; Ekim and Güner, 1986; Hedge, 1986; Davis et al., 1988; Mill, 1994; Ekim et al., 2000; Çolak and Rotherham, 2006; Güner et al., 2012; Sales and Hedge, 2013; Vanderplank et al., 2014; Eken et al., 2016), but none of these has used formal quantitative approaches to identify CEs and AEs.

In this study, CEs and AEs of the Turkish flora are identified based on data from three families of vascular plants (Asteraceae, Lamiaceae, Boraginaceae). These are among the most species-rich plant families in Turkey and constitute a significant proportion of the endemic flora of Turkey (c. 30\%). In order to identify CEs, three biodiversity indices, i.e., Endemic Richness (ER), Rangerestricted Endemic Richness (RER), and Weighted Endemic Richness (WER; referred to as Endemism Richness by Kier et al., 2009), were applied (Crisp et al., 2001; Linder, 2001); in order to identify AEs, Endemicity Analysis (Szumik et al., 2002) was used, which has been successfully applied in different parts of the world (Martínez-Hernández et al., 2015; Mendoza-Fernández et al., 2015; Szumik and Goloboff, 2015; Elías and Aagesen, 2016; Hoffmeister and Ferrari, 2016; Zhang et al., 2016; Weirauch et al., 2017; Noroozi et al., 2018). We address the following questions: (1) Where are the CEs and AEs in Turkey? (2) Are these exclusively inside global biodiversity hotspots? (3) Are these congruent with chorological patterns or hotspots identified in previous phytogeographical studies? (4) Is there a relation between topographical heterogeneity and endemic richness as suggested for other areas (Irl et al., 2015; Noroozi et al., 2018)?

\section{MATERIALS AND METHODS}

\section{Study Area}

Turkey is a mountainous country in Southwest Asia (97\% in Asia and $3 \%$ in Europe) covering c. $783,000 \mathrm{~km}^{2}$, with an average elevation of $1,130 \mathrm{~m}$ a.s.l. The elevation ranges from sea level up to $5,137 \mathrm{~m}$ a.s.l. in Mt. Ararat. According to their landform features, mountain ranges of Turkey can be geographically divided into Thrace, the Aegean zone, Taurus and Anti-Taurus ranges, the inner Anatolian Plateau, Pontic Mountains, and the Hakkari highlands (Zohary, 1973). The Anatolian Plateau stretches from southwestern to eastern Turkey near the border to Iran, where it merges with the Zagros Mountains in the southeast and the Transcaucasus highland in the east (Figure 1). The climate regime is very diverse ranging from temperate climate in the north, continental climate in the central parts, and Mediterranean climate in the south west (Akman and Ketenoğlu, 1986). Taurus and the Pontic Mountains in the south and north, respectively, shelter Central Anatolia from major precipitation, rendering this region very dry (Akman and Ketenoğlu, 1986). Due to the complex topography and climate, plant diversity is very high (Davis, 1971; Zohary, 1973; Akman and Ketenoğlu, 1986). Three major phytogeographical regions, i.e., the IranoTuranian, the Euro-Siberian and the Mediterranean, meet in Turkey. The Irano-Turanian region covers major parts of the Anatolian Plateau, bounded on the north by the Euro-Siberian region and in the west and southwest by the Mediterranean region (Figure 1; Davis, 1971). 

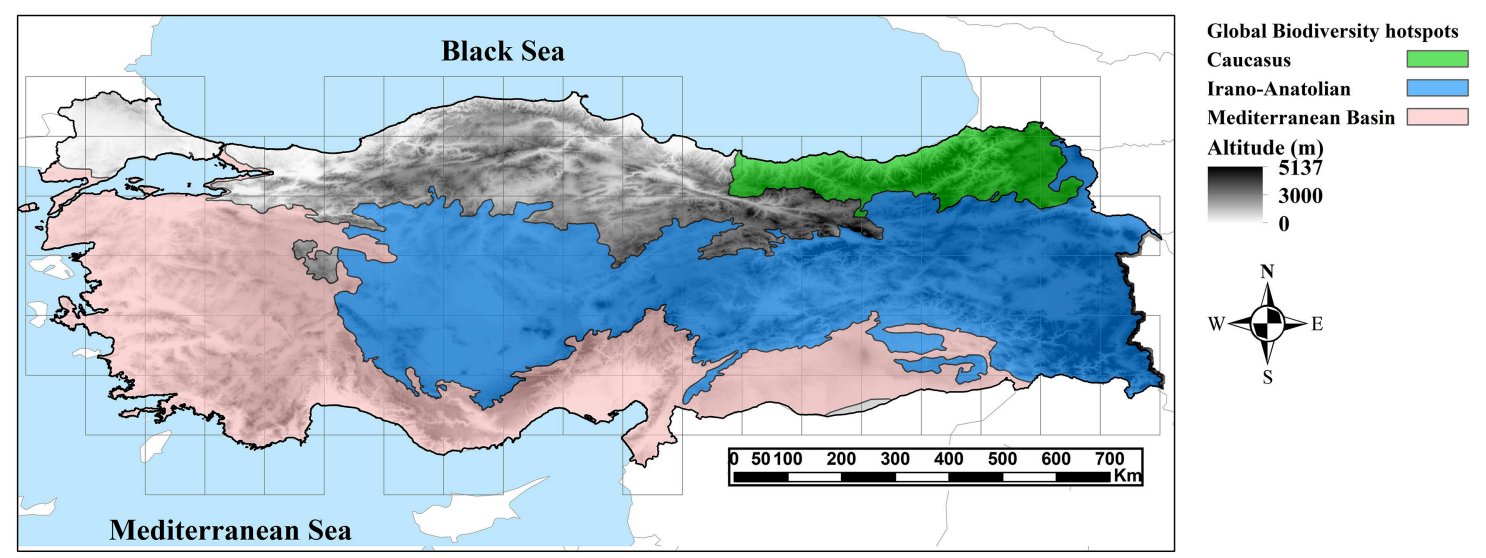

FIGURE 1 | Topographic map of the study area (Turkey) showing the extent of three global biodiversity hotspots in this region.

\section{Distributional Data}

We selected Asteraceae, Lamiaceae, and Boraginaceae as our model groups as they are among the most species-rich families of Turkey (first, third, and eighth, respectively; Davis, 1965-1985) and jointly are found in all environments and across all elevational zones. For Iran, inferences based on Asteraceae alone (Noroozi et al., 2018) and on the recently completed data set for the entire endemic flora (Noroozi et al., submitted) turned out to be largely congruent, emphasizing that a few large and diverse families can be used in cases where obtaining data on the entire flora is not possible. The data set comprises 1,102 endemic taxa (879 species, 146 subspecies, 77 varieties), 640 of which are from Asteraceae, 316 from Lamiaceae, and 146 from Boraginaceae (see Electronic Supplementary Material S1 in Supporting Information for detailed information); subendemic taxa (i.e., taxa to a minor extent also occurring outside the study region) were not considered. Distribution data were taken from the Flora of Turkey (Davis, 1965-1985), supplemented by data on new species published after this flora (see Electronic Supplementary Material S1 for details). A total of 3,867 records were geo-referenced with a precision of at least $0.25^{\circ}$.

\section{Data Analyses}

The size of grid cells to measure CEs and AEs was $1^{\circ} \mathbf{x}$ $1^{\circ}$; smaller grid sizes were not used to decrease the effects of sampling artifacts, whereas larger grid cell sizes (ca. $2.5^{\circ}$ x $2.5^{\circ}$ ) as suggested by NDM based on point densities (program option "autogrid") were not used as they would result in environmentally overly heterogeneous grid cells. Three quantitative measures of CEs, i.e., Endemic Richness (ER), Range-restricted Endemic Richness (RER), and Weighted Endemic Richness (WER), were applied (Williams, 2000; Crisp et al., 2001; Linder, 2001). Endemic Richness is calculated as the number of endemics present in a grid cell. Taxa present in maximally 3 grid cells in size of $0.5^{\circ} \times 0.5^{\circ}$ were categorized as narrowly distributed or range-restricted. These taxa were used to calculate RER. To make use of the full data set, but more strongly emphasize range-restricted taxa, species were inversely weighted (WER) by the range size (i.e., the score of each species is calculated as $1 /$ number of grid cells the species occurs in), and the sum of the weights of the species of each cell gives the score of that cell (Williams, 2000). Thus, areas with many range-restricted taxa should get a higher total score than areas with few range-restricted taxa. Ten percent of cells with the highest index values were used to define hotspots.

Endemicity Analysis (Szumik and Goloboff, 2004) as implemented in the program NDM/VNDM 3 (Goloboff, 2007) was used to identify AEs. An endemicity score was calculated as the sum of the endemicity scores of each supporting species for each recognized AE (Szumik and Goloboff, 2004). The parameters used in the analysis were as follows: sets must have an endemicity score of at least 2 with at least 10 supporting taxa; temporarily saving sets within 0.99 of the current score; keeping overlapping subsets when $30 \%$ of the taxa were unique; 100 replicates. Consensus areas were constructed to reduce the level of redundancy in the inferred AEs (Aagesen et al., 2013). Thus, the loose consensus rule was used (considered sufficiently detailed for large-scale studies: Aagesen et al., 2013), i.e., areas were added when each area shares at least $25 \%$ of its defining taxa with at least one, but not necessarily all, of the other areas in the consensus. The list of taxa contributing to the scores of each identified AEs is provided in Electronic Supplementary Material S2. Relationships between ER or RER per raster-cell on one side to topographical complexity or elevational amplitude on the other side were tested using Generalized Linear Models (GLM) with a Poisson distributed response (species richness) and the canonical log link-function (function glm in R Core Team, 2015). Topographic complexity was calculated as the ratio of $3 \mathrm{D}$ Area (= surface area; extracted from a digital elevation model with a resolution of $100 \mathrm{~m}$, available at https://www.eea.europa.eu/data-and-maps/data/ copernicus-land-monitoring-service-eu-dem) to 2D Area as decribed by Irl et al. (2015) using the extension DEM Surface 
Tools for ArcGIS (Jenness, 2004, 2013) in ArcGIS 10 (Esri, Redlands, CA, USA).

\section{RESULTS}

Of the 99 analyzed genera, Centaurea (Asteraceae) is the largest genus in the dataset with 156 taxa, followed by Hieracium (Asteraceae; 69 taxa), Onosma (Boraginaceae; 52 taxa), Salvia (Lamiaceae; 50 taxa), Anthemis (Asteraceae; 47 taxa), Stachys (Lamiaceae; 44 taxa), and Scorzonera (Asteraceae; 35 taxa). The range sizes of endemic taxa are between one and 22 cells. These endemics are unevenly distributed in Turkey. The endemic richness of cells ranges from 1 to 129 , the value of the highest endemic richness overall corresponding to the western Taurus (Figure 2A). A total of 798 taxa are known as range-restricted, i.e., are present in maximally three cells (size of $0.5^{\circ} \times 0.5^{\circ}$ ). The results of three indices to find CEs are largely congruent (Figure 2). Using a cut-off of 10\%, a total of 14 grid cells belonging to CEs are identified as hotspots by at least one of the indices and seven cells are identified as hotspots supported by all three indices (Figure 2D). All identified CEs are within global biodiversity hotspots.

The Endemicity Analysis identified 68 sets (candidate AEs), which were grouped into four consensus areas with minimum and maximum scores of 6.49 and 25.76, respectively (Figure 3). All identified AEs are within a global biodiversity hotspot. A comparison of herein identified CEs and AEs with centers of plant endemic diversity identified previously is shown in Figure 4.

The West-Taurus AE contains 17 sets, comprises 17 grid cells, and covers mountains of south-western Turkey, which mainly belong to the Mediterranean region (Figure 3A). The endemicity scores of the area range from 6.97 to 25.76 . The area is supported by 107 taxa contributing to the scores. Within this AE, four cells are identified as CEs; three of those are supported by all three indices and one is supported by two indices (Figure 2D).

The Anatolian Diagonal AE contains 37 sets, comprises 27 grid cells and covers Taurus and mountains of Inner Anatolia (Figure 3B). The endemicity scores of the area range from 6.49 to 16.97 . It is supported by 125 taxa contributing to the scores. A total of ten CEs are identified inside this AE, two of which are shared with the Western-Taurus AE (one cell supported by all indices and one cell by two indices), and three of which are shared with the Pontic-Ala AE (one cell supported by all indices, one cell by two indices and one by only one index). Of the remaining five CEs, two cells are supported by all indices; two cells by two indices and one cell by only one index (Figure 2D).

The Pontic-Ala AE contains 13 sets, comprises 17 grid cells and covers the Pontic Mountains in northeastern Turkey (Figure 3C). The endemicity scores of the area range from 6.58 to 13.69. The area is supported by 53 taxa contributing to the score. Four cells are identified as CEs inside of this AE, three of which are shared with the Anatolian Diagonal AE. One non-shared cell with previous area is supported by two indices (Figure 2D).

The Hakkari AE contains a single set, comprising four grid cells and covering mountains of the Hakkari highland in southeastern Turkey (Figure 3D). The endemicity scores of the area range from 8.50 to 8.75 . The area is supported by 12 taxa contributing to the scores, but does not include any CE.

Both ER and RER were positively related to topographic complexity and especially to elevational amplitude (Figure 5; Table 1). Proportional surface area and endemic richness in elevational range were not congruently distributed (Figure 6). Both were hump-shaped, but the surface area peaked sharply at $1,000 \mathrm{~m}$ a.s.l., whereas endemic richness gradually increased until $1,700 \mathrm{~m}$ a.s.l, and then sharply decreased parallel with surface area.

\section{DISCUSSION}

Using quantitative methods, $14 \mathrm{CEs}$ as well as four AEs are identified in Turkey based on data of three species-rich families of vascular plants. These hotspots are well associated with the high mountain ranges of the region. All CEs, except one, are inside the identified AEs, and all AEs are located within global biodiversity hotspots, representing "hotspots-within-hotspots" (Figures 2, 3). The single CE not covered by any AE includes an isolated mountain range in northwestern Turkey (Uludağ, $2,543 \mathrm{~m}$ a.s.l.). This mountain is already known as an area with high conservation priority due to its rich plant species and endemic diversity (see Figure 4; Ekim et al., 2000; Daşkin and Kaynak, 2010; Senkul and Kaya, 2017).

The West-Taurus AE is mainly associated with the Mediterranean biodiversity hotspot and has the highest endemicity score among all identified AEs (Figure 3). The richest area in Turkey according to ER (129 species) and RER (61 species) is inside this AE (Figures 2A,B). The West-Taurus $\mathrm{AE}$ includes complex mountain systems exceeding 3,000 $\mathrm{m}$ a.s.l., such as Bey Dağlari. High elevational amplitude and climatic diversity result in high habitat heterogeneity, ranging from sea level lowlands up to alpine habitats, and thus supports high plant diversity and endemism. The Western Taurus has been recognized before as a center of plant diversity (Davis, 1971; Ekim et al., 2000; Eren et al., 2004).

The Anatolian Diagonal AE is the biggest AE identified in this study with a high number of CEs (ten cells). It covers the Mediterranean hotspot in southern Turkey and parts of the Irano-Anatolian hotspot from Inner Anatolia to the Pontic Mts. in northeastern Turkey (Figure 3B). This AE supports a previously identified distribution pattern named "Anatolian Diagonal" by Davis (1971), constituting a remarkable floristic break through the middle of Inner Anatolia, which stretches from the Taurus mountains in southern Turkey to northeast Turkey (Davis, 1971; Ekim and Güner, 1986). This diagonal system is considered the migration corridor to the south for Euro-Siberian species during glacial phases of the Pleistocene (Davis, 1971; Ansell et al., 2011). Three CEs, supported by all three indices, cover the central Taurus and show the highest conservation priority of these mountains. The Taurus mountains are extremely rich in their flora, endemics and vegetation types due to the remarkable bioclimatic, geomorphological, and pedological diversity (Parolly, 2004, 2015). Although Taurus is mainly within 

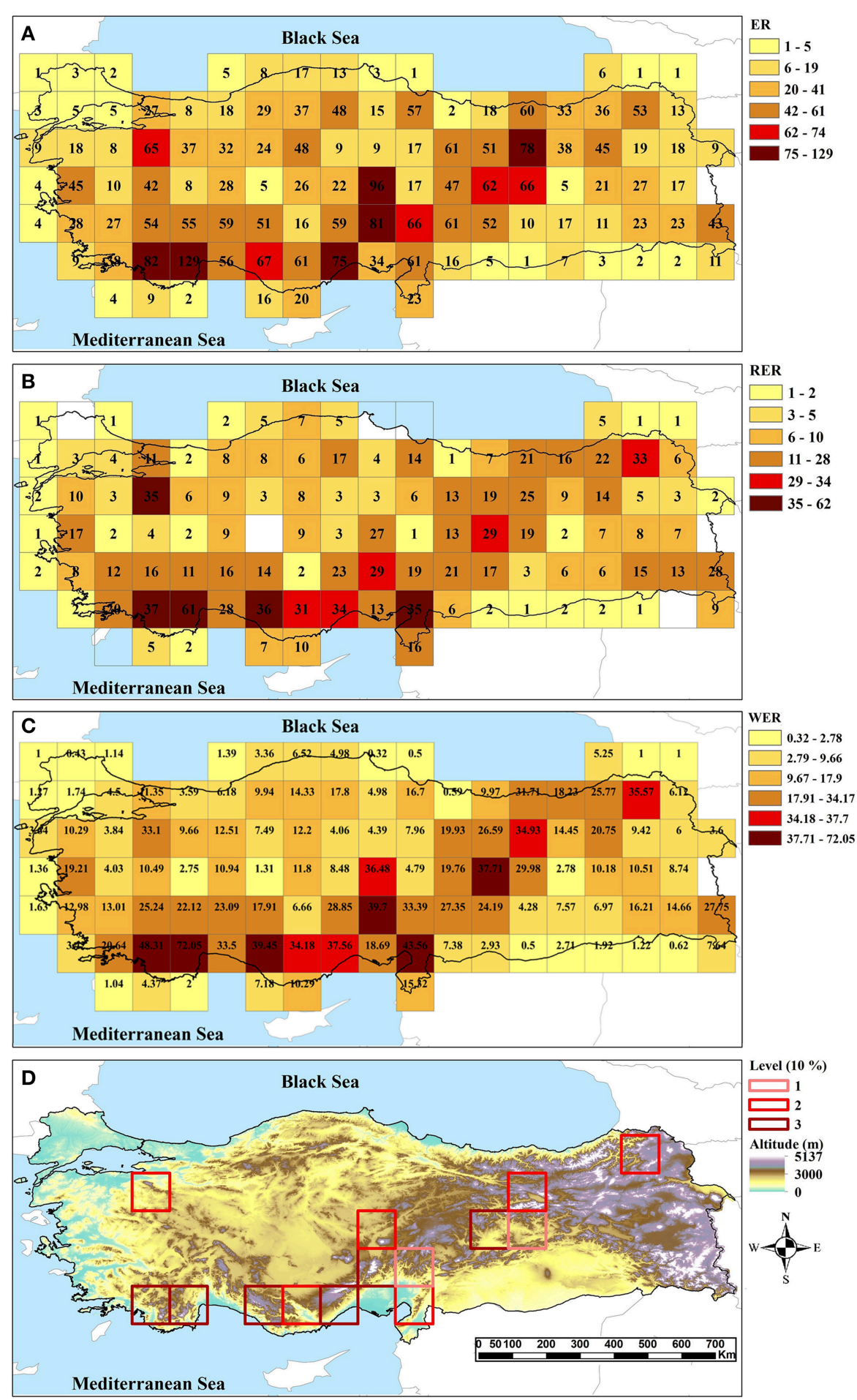

FIGURE 2 | Centers of endemism in the study area identified by (A) endemic richness, (B) range-restricted endemic richness, (C) weighted endemic richness, and (D) their intersection (1: supported by one index, 2: supported by two indices, 3: supported by three indices). In (A-C) the two highest categories correspond to the 5 and $10 \%$ richest cells.

the Mediterranean region, elements of the alpine zone belong to the Irano-Turanian floristic region (Runemark, 1971). Another $\mathrm{CE}$, identified in the northeast of this AE (Figure 2), covers high mountains of Munzur Dağlari. This CE is partly covered by the Munzur Valley National Park, which is the largest national park in Turkey. 


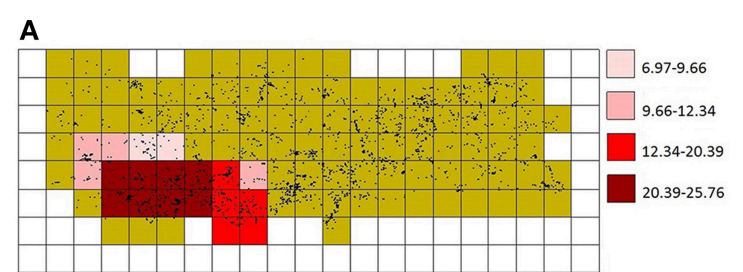

C

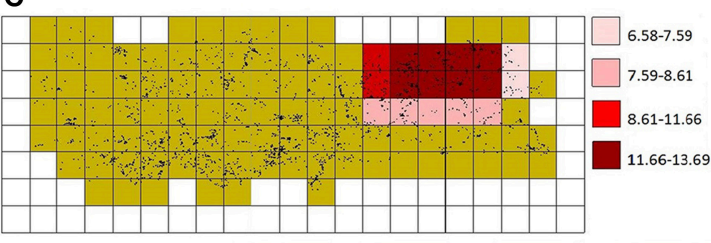

B

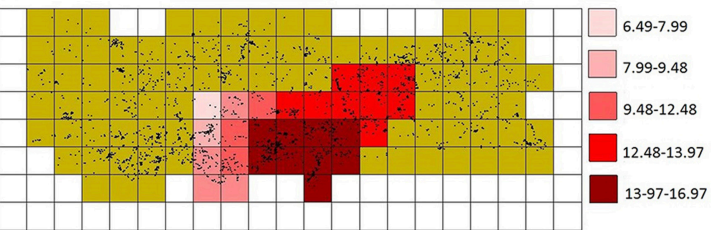

D

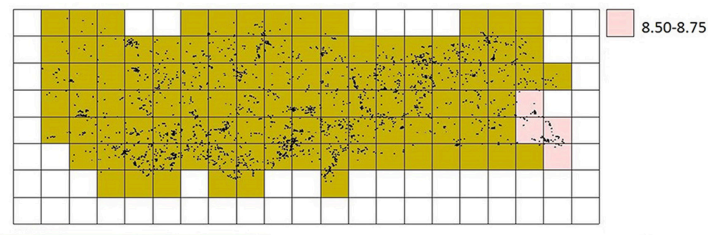

E Black Sea

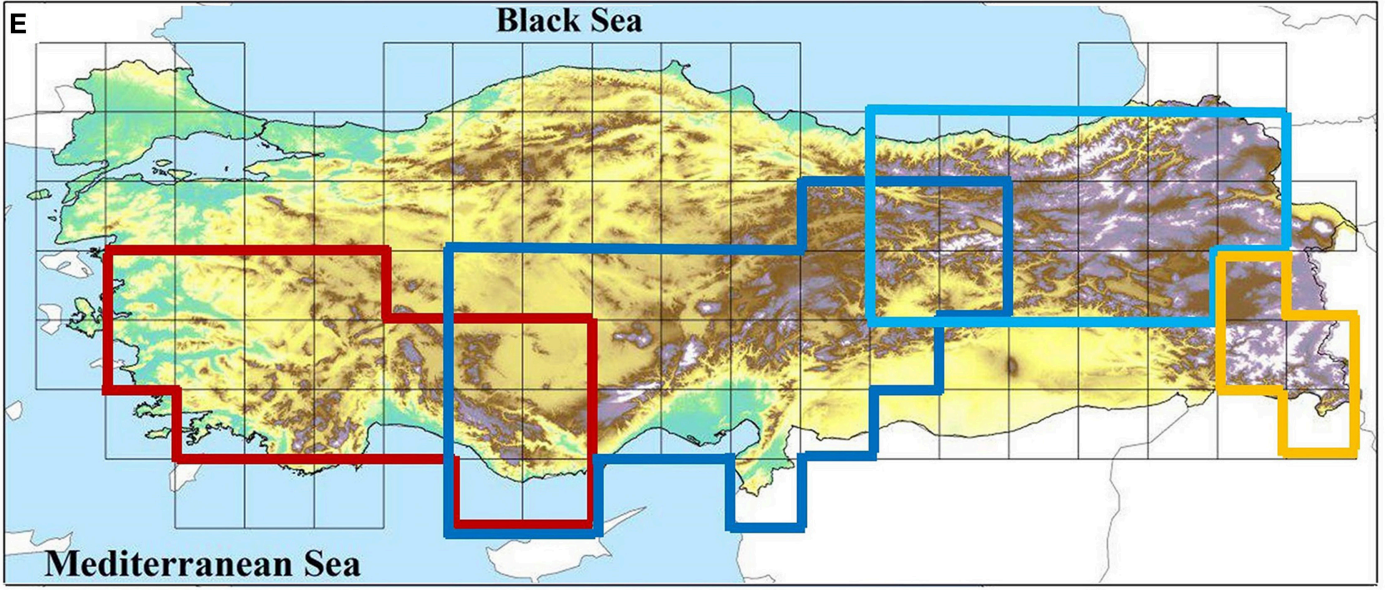

FIGURE 3 | Areas of endemism (AEs) in the study area (A) West-Taurus AE, (B) Anatolian Diagonal AE, (C) Pontic-Ala AE, (D) Hakkari AE, and (E) their overlap. Dots in (A-D) indicate the data points used in this study.

The Pontic-Ala AE reaches from the Irano-Anatolian hotspot to the Caucasian hotspot. The endemicity score is high in Munzur, Ala and Pontic mountains. The area contains heterogeneous topography and climate and is connected to highlands of the Transcaucasus region. This area includes Munzur Daǧlari, where it overlaps with the Anatolian Diagonal AE. As already noted by Zohary (1973) and Davis (1971), northeastern Turkey as part of the Caucasian region is much richer in endemics compared to the remaining Euro-Siberian part of Turkey. This area (Colchic region) served as a refugium in the Euro-Siberian floristic region during the Pleistocene glacial periods, similar to the Hyrcanian forests at the northern slopes of Alborz (Rokas et al., 2003; Dubey et al., 2006), what might be one of the major reasons for the high diversity in endemics.

Hakkari AE is close to the border of Iran and Iraq and within the Irano-Anatolian hotspot. The endemicity score is low and no CE was identified. The high mountains of this region are floristically well-connected to the Zagros Mts. and the Azerbaijan Plateau in northwestern Iran (Akhani, 2007; Noroozi et al., 2014), and the floristic affinity with mountains of neighboring countries is stronger than in other parts of Anatolia (Vanderplank et al., 2014). Therefore, many of the narrowly distributed species reach beyond the border of Turkey and thus were not included in our analysis. In spite of this, a cell with only $2 / 3$ of its area within the study region has 28 range-restricted taxa (Figure $2 \mathrm{~B}$ ), which is just one species short of the threshold for the $10 \%$ richest cells (i.e., 29 taxa per cell). The situation may be exacerbated as the sampling density of the region is lower than in other regions of Turkey. Still, the area was recognized before as one of the important areas of Turkey for plant diversity (Davis, 1971; Ekim et al., 2000; Ünal and Behçet, 2007; Senkul and Kaya, 2017).

Both the Anatolian Diagonal and Pontic-Ala AEs intersect two biogeographical regions and two biodiversity hotspots. In these areas, alpine habitats are playing an important role and alpine species constitute a large proportion of their flora (Zohary, 1971; Hein et al., 1998; Kürschner et al., 1998; Parolly, 2015), and these species act as bridges connecting different biogeographical regions to each other.

Our study largely supports centers of plant diversity in Turkey already recognized by previous authors. For example Mill (1994) ranks the entire Taurus, Anatolian Diagonal and eastern Pontus among the most important centers of plant diversity in SW Asia. Moreover, the important areas for endemic plants of Turkey (Ekim et al., 2000) and plant endemic hotspots of Turkey (Türe and Böcük, 2010; Senkul and Kaya, 2017) are largely congruent with our results (Figure 4). However, there 
A

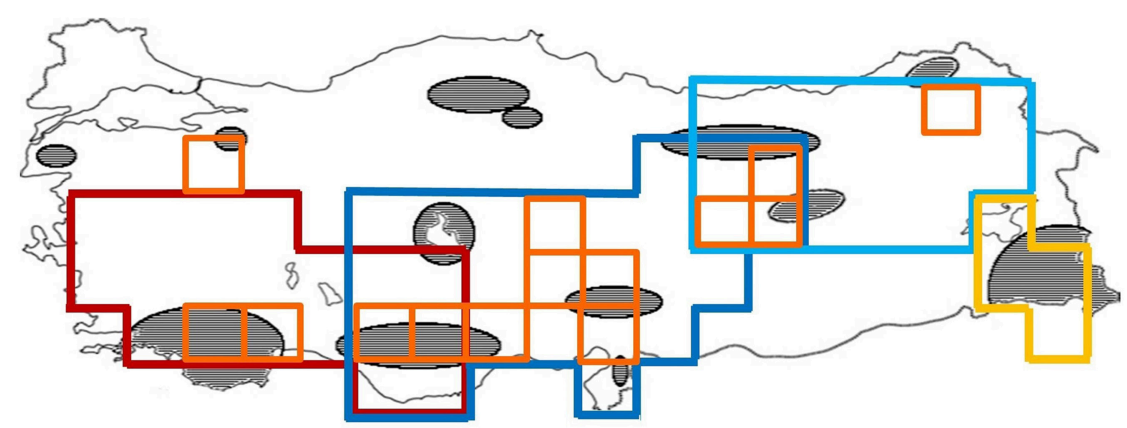

B

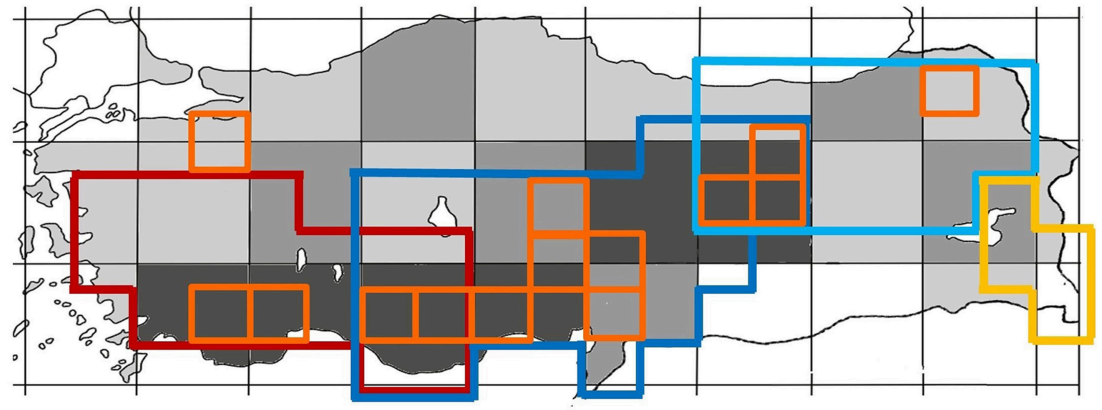

C

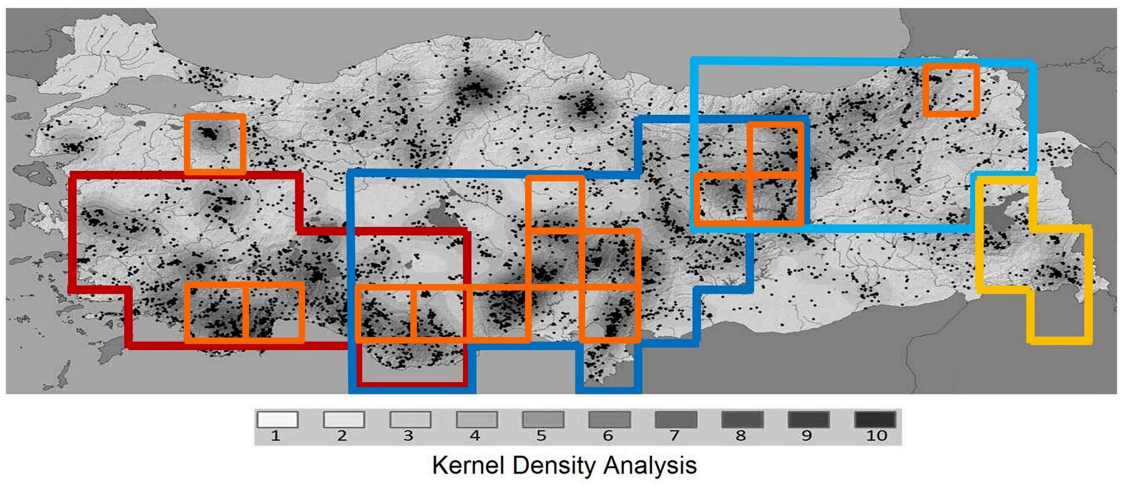

FIGURE 4 | Comparison of centers of endemism and areas of endemism identified in this study with centers of plant endemic diversity in Turkey identified previously by (A) Ekim et al. (2000), (B) Türe and Böcük (2010), (C) Senkul and Kaya (2017).

are some hotspots in previous studies which our results do not support. These areas are in north Turkey (Figures 4A,C), but none of our used indices support them as $10 \%$-richest areas of Turkey. This can be due to methodological differences, including using different thresholds to identify hotspots (Figure 4A), big grid sizes (Figure $4 \mathrm{~B}$ ), or using the number of recorded localities of endemics instead of the number of endemics (Figure 4C).

Topographic heterogeneity is one of the key environmental predictors of species richness (Qi and Yang, 1999; Irl et al., 2015) and, in extension, of endemic species richness. With increasing topographic heterogeneity environmental heterogeneity is expected to increase (Scherrer and Körner, 2010; Irl et al., 2015), resulting in high habitat diversity and a large local niche space (Scherrer and Körner, 2011; Hortal et al., 2013). High habitat diversity promotes ecological speciation (Steinbauer et al.,
2013) and can increase the diversity of local refugia for species to survive Quaternary climate fluctuations (Ashcroft et al., 2012), jointly contributing to increasing richness of endemics in topographically complex mountain ranges.

The endemic taxa of the Anatolian Plateau are concentrated at mid-elevations, a general trend of mountain biota first proposed by Rahbek (1997) also found in the eastern part of the Irano-Anatolian region (Mahdavi et al., 2013; Noroozi et al., 2018). The sharp decrease of endemic richness above $1,700 \mathrm{~m}$ a.s.l. may be due to the decrease of surface area and the environmental stress imposed by cold habitats. Although endemic richness decreases beyond a certain elevation, the proportion of endemics is expected to increase along the elevational gradient (Noroozi et al., 2011, 2018), something we cannot test yet for Turkey in the absence of sufficiently 

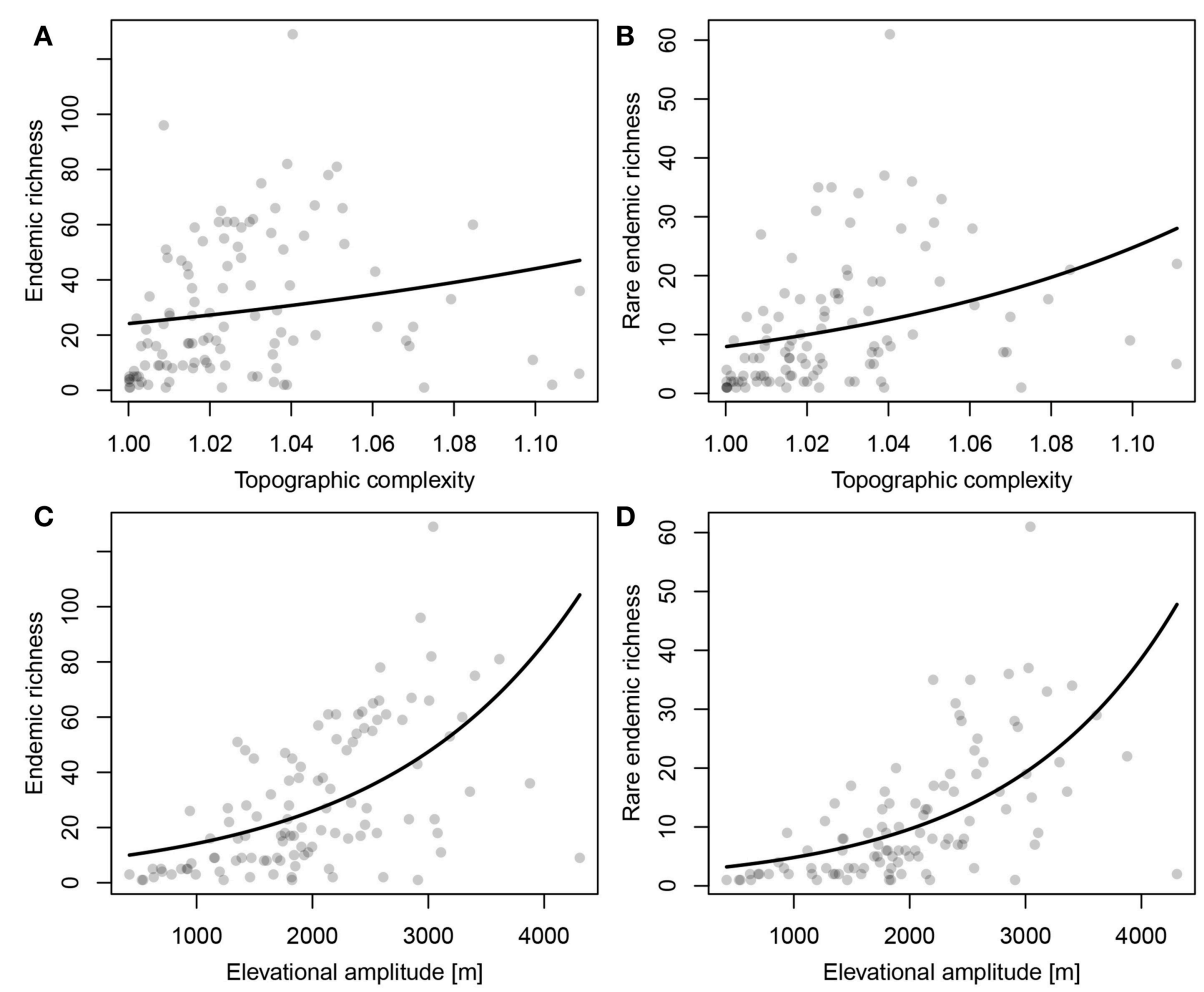

FIGURE 5 | Relationships between (A,C) Endemic Richness (ER) and (B,D) Range-restricted Endemic Richness (RER) per raster-cell and (A,B) topographic complexity and (C,D) elevational amplitude.

detailed information on the overall floristic composition across elevations.

Although the three plant families investigated by us encompass a significant proportion of Turkey's plant diversity (ca. $30 \%$ of endemics) and jointly occur in all environments and across all elevational zones, using only a subset of the vascular plant flora may introduce a bias, as generally poorly studied regions will be insufficiently represented likely increasing inequalities in geographic coverage due to geographically differing collecting intensities. Including more data, ideally from the entire endemic flora, as well as floristic field research will be necessary to remedy this. Endemic species have been shown to be a reliable substitute for overall biodiversity (Domínguez et al., 2006; Lamoreux et al., 2006), but including only endemic species is expected to introduce an edge effect, especially if the used boundaries are biogeographically rather meaningless (as certainly is the case in southeastern Turkey). This can be alleviated by using the entire instead of only the endemic flora (Edler et al., 2017), which currently for Turkey is not possible because of the prohibitively big efforts necessary to obtain sufficient georeferenced data.

\section{CONCLUSION}

Mountains are biodiversity hotspots (Spehn et al., 2011) and influence the distribution and diversification of species over
TABLE 1 | Relationships between Endemic Richness (ER) and Range-restricted Endemic Richness (RER) per raster-cell using Generalized Linear Models (GLM) with a Poisson distributed response (species richness) and the canonical log link-function.

\begin{tabular}{lccccc}
\hline- & Estimate & Std. error & z-value & $\operatorname{Pr}(>|\mathbf{z}|)$ & D2 \\
\hline $\begin{array}{l}\text { ER } \sim \text { Topographic } \\
\text { complexity }\end{array}$ & 6.01 & 0.66 & 9.17 & $<0.001$ & 0.03 \\
$\begin{array}{l}\text { RER } \sim \text { Topographic } \\
\text { complexity }\end{array}$ & 11.37 & 1.02 & 11.11 & $<0.001$ & 0.11 \\
$\begin{array}{l}\text { ER } \sim \text { Elevational } \\
\text { amplitude }\end{array}$ & $6.03 E-04$ & $2.18 \mathrm{E}-05$ & 27.68 & $<0.001$ & 0.31 \\
$\begin{array}{l}\text { RER } \sim \text { Elevational } \\
\text { amplitude }\end{array}$ & $6.94 \mathrm{E}-04$ & $3.56 \mathrm{E}-05$ & 19.48 & $<0.001$ & 0.38 \\
& & & & & \\
\hline
\end{tabular}

time (Hoorn et al., 2018). Mountains with high topographic complexity, isolation and diverse micro-climates support high biodiversity and endemism (Irl et al., 2015; Steinbauer et al., 2016), which is also the case for the mountains of SW Asia (Vanderplank et al., 2014; Noroozi et al., 2018). High mountains of Anatolia have played an important role in definition of biogeographical subregions (Çiplak, 2003, 2004), and the transitional biogeographical position of Anatolia likely supports high speciation (Davis, 1971; Parolly, 2004; Parolly et al., 2010). Glacier development within Anatolia during the Pleistocene was limited to higher mountains (Atalay, 1996), while the lowlands harbored steppe communities 


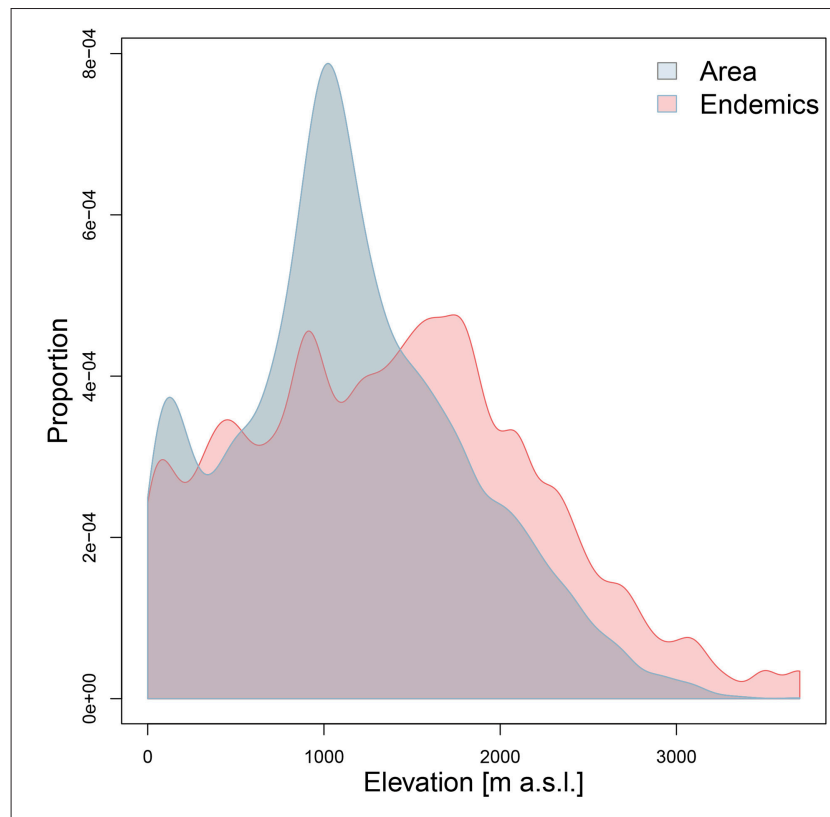

FIGURE 6 | Proportion of total surface area and endemic richness along the elevational gradient.

(Michaux et al., 2004; Magyari et al., 2008). Therefore, lowlands and lower montane zones are considered suitable habitats for temperate species to survive the last glacial maximum (Rokas et al., 2003; Dubey et al., 2006, 2007; Fritz et al., 2009; Ahmadzadeh et al., 2013).

Our identified CEs cover 16\% of Turkey's surface area but harbor $59 \%$ of this country's endemic taxa highlighting their conservation priority. In the high mountains of Anatolia, the rate of endemism increases sharply along an elevational gradient (Hein et al., 1998; Kürschner et al., 1998; Parolly, 1998, 2004, 2015) as is the case in the high mountains of the Iranian Plateau (Noroozi et al., 2011, 2018), making the high elevation habitats of these mountains extremely important in terms of biodiversity

\section{REFERENCES}

Aagesen, L., Szumik, C. A., and Goloboff, P. A. (2013). Consensus in the search for areas of endemism. J. Biogeogr.40, 2011-2016. doi: 10.1111/jbi.12172

Ahmadzadeh, F., Flecks, M., Rödder, D., Böhme, W., Ilgaz, Ç., Harris, D. J., et al. (2013). Multiple dispersal out of Anatolia: biogeography and evolution of oriental green lizards. Biol. J. Linnean Soc. 110, 398-408. doi: 10.1111/bij. 12129

Akhani, H. (2007). Diversity, biogeography, and photosynthetic pathways of Argusia and Heliotropium (Boraginaceae) in South-West Asia with an analysis of phytogeographical units. Botan. J. Linnean Soc. 155, 401-425. doi: 10.1111/j.1095-8339.2007.00707.x

Akman, Y., and Ketenoğlu, O. (1986). The climate and vegetation of Turkey. Proc. Royal Soc. Edinburgh Sect. B 89, 123-134.

Anderson, S. (1994). Area and endemism. Q. Rev. Biol. 69, 451-471.

Ansell, S. W., Stenøien, H. K., Grundmann, M., Russell, S. J., Koch, M. A., Schneider, H., et al. (2011). The importance of Anatolian mountains as the cradle of global diversity in Arabis alpina, a key arctic-alpine species. Ann. Bot. 108, 241-252. doi: 10.1093/aob/mcr134 conservation. Mountain species, especially cold adapted ones in the alpine zone, are considered to be among the most strongly affected by global climate change (Engler et al., 2011; Dullinger et al., 2012). A decline of high-altitude habitats through climate warming and reduced water availability in this region likely is expected to threaten the survival of the unique cryophilic high mountain flora of Anatolia (Parolly, 2015). On the other hand, most of the high mountains in Turkey are threatened by severe overgrazing (Kürschner and Parolly, 2012) and other human activities such as construction of touristic infrastructure (Daşkin and Kaynak, 2010). The majority of the endemic species of Turkey are narrowly distributed and threatened (Türe and Böcük, 2010). Only a small fraction of these species is distributed in protected areas indicating a strong conservation gap (Amarli et al, 2016). Thus, focusing on the conservation of the identified hotspots, ideally refined by using data from the entire flora and relevant animal groups, and applying dedicated software such as Marxan (Ball et al., 2009; Mendoza-Fernández et al., 2015) will assist to protect a high number of threatened narrowly distributed taxa.

\section{AUTHOR CONTRIBUTIONS}

JN conceived the ideas. GZ, MS, and ZA were involved with collecting the data. JN, MM, and DM analyzed the data. JN and GS led the writing with all co-authors contributing.

\section{FUNDING}

This project was funded by the Austrian Science Fund (FWF, P28489-B29 to GS).

\section{SUPPLEMENTARY MATERIAL}

The Supplementary Material for this article can be found online at: https://www.frontiersin.org/articles/10.3389/fevo. 2019.00159/full\#supplementary-material
Ashcroft, M. B., Gollan, J. R., Warton, D. I., and Ramp, D. (2012). A novel approach to quantify and locate potential microrefugia using topoclimate, climate stability, and isolation from the matrix. Glob. Chang. Biol. 18, 1866-1879. doi: 10.1111/j.1365-2486.2012.02661.x

Atalay, I. (1996). Palaeosols as indicators of the climatic changes during Quaternary period in S. Anatolia. J. Arid Environ. 32, 23-35. doi: 10.1006/jare.1996.0003

Ball, I. R., Possingham, H. P., and Watts, M. (2009). "Marxan and relatives: Software for spatial conservation prioritization," in Spatial Conservation Prioritization: Quantitative Methods and Computational Tools, eds A. Moilanen, K. A. Wilson and H. P. Possingham (Oxford: Oxford University Press), 185-195.

Bradshaw, P. L., Colville, J. F., and Linder, H. P. (2015). Optimising regionalisation techniques: identifying centres of endemism in the extraordinarily endemic-rich Cape floristic region. PLOS ONE 10:e0132538. doi: 10.1371/journal.pone.0132538

Brooks, T. M., Mittermeier, R. A., da Fonseca, G. A. B., Gerlach, J., Hoffmann, M., Lamoreux, J. F., et al. (2006). Global biodiversity conservation priorities. Science 313, 58-61. doi: 10.1126/science. 1127609 
Cañadas, E. M., Fenu, G., Peñas, J., Lorite, J., Mattana, E., and Bacchetta, G. (2014). Hotspots within hotspots: endemic plant richness, environmental drivers, and implications for conservation. Biol. Conserv. 170, 282-291. doi: 10.1016/j.biocon.2013.12.007

Ceballos, G., Rodriguez, P., and Medellin, R. A. (1998). Assessing conservation priorities in megadiverse Mexico: mammalian diversity, endemicity, and endangerment. Ecol. Appl. 8, 8-17. doi: 10.2307/2641307

Çiplak, B. (2003). Distribution of Tettigoniinae (Orthoptera, Tettigoniidae) bushcrickets in Turkey: the importance of the anatolian taurus mountains in biodiversity and implications for conservation. Biodivers. Conserv. 12, 47-64. doi: 10.1023/A:1021206732679

Çiplak, B. (2004). Biogeography of Anatolia: the marker group Orthoptera. Memorie della Soc. Entomol. Itali. 82, 357-372.

Çolak, A. H., and Rotherham, I. (2006). A review of the forest vegetation of Turkey: its status past and present and its future conservation. Biol. Environ. Proc. Royal Irish Acad. 106, 343-354. doi: 10.3318/BIOE.2006.106.3.343

Crisp, M. D., Laffan, S., Linder, H. P., and Monro, A. (2001). Endemism in the Australian flora. J. Biogeogr. 28, 183-198. doi: 10.1046/j.1365-2699.2001.00524.x

Crosby, M. J. (1994). "Mapping the distributions of restricted range birds to identify global conservation priorities," in Mapping the Diversity of Nature, ed. R. I. Miller (London: Chapman and Hall), 145-154.

Daşkin, R., and Kaynak, G. (2010). Vascular flora of the Uludag Mt (Bursa, Turkey). Phytol. Balcan. 16, 369-411.

Davis, P. H. (1965-1985). Flora of Turkey and the east Aegean islands. Edinburgh: Edinburgh University Press.

Davis, P. H. (1971). "Distribution patterns in Anatolia with particular reference to endemism," in Plant Life of South-West Asia, eds. P. H. Davis, P. C. Harper and I. C. Hedge (Edinburgh: The Botanical Soiciety of Edinburgh), 15-27.

Davis, P. H., and Hedge, I. C. (1975). The flora of Turkey: past, present and future. Candollea 30, 331-351.

Davis, P. H., Mill, R. R., and Tan, K. (1988). Flora of Turkey and the East Aegean Islands, Vol. 10. Edinburgh: Edinburgh University Press.

Domínguez, M. C., Roig-Juñent, S., Tassin, J. J., Ocampo, F. C., and Flores, G. E. (2006). Areas of endemism of the Patagonian steppe: an approach based on insect distributional patterns using endemicity analysis. J. Biogeogr. 33, 1527-1537. doi: 10.1111/j.1365-2699.2006.01550.x

Dubey, S., Cosson, J.-F., Vohralik, V., Krystufek, B., Diker, E., and Vogel, P. (2007). Molecular evidence of Pleistocene bidirectional faunal exchange between Europe and the Near East: the case of the bicoloured shrew (Crocidura leucodon, Soricidae). J. Evol. Biol. 20, 1799-1808. doi: 10.1111/j.1420-9101.2007.01382.x

Dubey, S., Zaitsev, M., Cosson, J.-F., Abdukadier, A., and Vogel, P. (2006). Pliocene and Pleistocene diversification and multiple refugia in a Eurasian shrew (Crocidura suaveolens group). Mol. Phylogenet. Evol. 38, 635-647. doi: 10.1016/j.ympev.2005.11.005

Dullinger, S., Gattringer, A., Thuiller, W., Moser, D., Zimmermann, N. E., Guisan, A., et al. (2012). Extinction debt of high-mountain plants under twenty-first-century climate change. Nat. Clim. Chang. 2, 619-622. doi: $10.1038 /$ nclimate 1514

Edler, D., Zizka, A., Guedes, T., Rosvall, M., and Antonelli, A. (2017). Infomap bioregions: Interactive mapping of biogeographical regions from species distributions. Syst. Biol. 66, 197-204. doi: 10.1093/sysbio/syw087

Eken, G., Isfendiyaroglu, S., Yeniyurt, C., Erkol, I. L., Karataş, A., and Ataol, M. (2016). Identifying key biodiversity areas in Turkey: a multitaxon approach. Int. J. Biodiver. Sci. Ecosyst. Servic. Manage. 12, 181-190. doi: 10.1080/21513732.2016.1182949

Ekim, T., and Güner, A. (1986). The Anatolian diagonal: fact or fiction? Proc. Royal Soc. Edinburgh. Section B. Biol. Sci. 89, 69-77. doi: 10.1017/S0269727000 008915

Ekim, T., Koyuncu, M., Vural, M., Duman, H., Aytaç, Z., and Adigüzel, N. (2000). Red Data Book of Turkish Plants (Ptreidophyta and Spermatophyta). Ankara: Bariscan Ofset.

Elías, G. D.V., and Aagesen, L. (2016). Areas of vascular plants endemism in the Monte desert (Argentina). Phytotaxa 266, 161-182. doi: 10.11646/phytotaxa.266.3.1

Engler, R., Randin, C. F., Thuiller, W., Dullinger, S., Zimmermann, N. E., Araújo, M. B., et al. (2011). 21st century climate change threatens mountain flora unequally across Europe. Glob. Chang. Biol. 17, 2330-2341. doi: 10.1111/j.1365-2486.2010.02393.x

Eren, Ö., Gökçeoğlu, M., and Parolly, G. (2004). The flora and vegetation of Bakırlı Daği (Western Taurus Mts, Turkey), including annotations on critical taxa of the Taurus range. Willdenowia 34, 463-503. doi: 10.3372/wi.34.34212

Fritz, U., Ayaz, D., Hundsdörfer, A. K., Kotenko, T., Guicking, D., Wink, M., et al. (2009). Mitochondrial diversity of European pond turtles (Emys orbicularis) in Anatolia and the Ponto-Caspian region: multiple old refuges, hotspot of extant diversification and critically endangered endemics. Organi. Diver. Evol. 9, 100-114. doi: 10.1016/j.ode.2009.02.002

Goloboff, P. A. (2007). NDM/VNDM; Programs for Identification of Areas of Endemism, Version 2.7. Available online at: www.lillo.org.ar/phylogeny/ (accessed May 3, 2019)

Güner, A., Aslan, S., Ekim, T., Vural, M., and Babaç, M. T. (2012). Türkiye Bitkileri Listesi (Damarli Bitkiler). Nezahat Gökyigit Botanik Bahçesi ve Flora Araştirmalari Dernegi Yayini. Istanbul: Flora Dizisi 1. Istanbul: Derneǧi Yayını.

Harris, G. M., Jenkins, C. N., and Pimm, S. L. (2005). Refining biodiversity conservation priorities. Conserv. Biol. 19, 1957-1968. doi: 10.1111/j.1523-1739.2005.00307.x

Hedge, I. C. (1986). Labiatae of South-West Asia: diversity, distribution and endemism. Proc. Royal Soc. Edinburgh Section B: Biol. Sci. 89, 23-35. doi: $10.1017 /$ S0269727000008873

Hein, P., Kürschner, H., and Parolly, G. (1998). Phytosociological studies on high mountain plant communities of the Taurus mountains (Turkey). 2. Rock communities. Phytocoenologia 28, 465-563. doi: 10.1127/phyto/28/19 98/465

Hoffmeister, C. H., and Ferrari, A. (2016). Areas of endemism of arthropods in the Atlantic Forest (Brazil): an approach based on a metaconsensus criterion using endemicity analysis. Biol. J. Linnean Soc. 119, 126-144. doi: 10.1111/bij.12802

Hoorn, C., Perrigo, A., and Antonelli, A. (2018). Mountains, Climate and Biodiversity. Oxford: Wiley-Blackwell.

Hortal, J., Carrascal, L. M., Triantis, K. A., Thébault, E., Meiri, S., and Sfenthourakis, S. (2013). Species richness can decrease with altitude but not with habitat diversity. Proc. Natl. Acad. Sci. USA. 110, E2149-E2150. doi: $10.1073 /$ pnas. 1301663110

Irl, S. D. H., Harter, D. E. V., Steinbauer, M. J., Gallego Puyol, D., FernándezPalacios, J. M., Jentsch, A., et al. (2015). Climate vs. topography - spatial patterns of plant species diversity and endemism on a high-elevation island. J. Ecol. 103, 1621-1633. doi: 10.1111/1365-2745.12463

Jenness, J. (2013). DEM Surface Tools for ArcGIS (surface_area.exe). Jenness Enterprises. Available online at: http://www.jennessent.com/arcgis/surface area.htm (accessed May 3, 2019)

Jenness, J. S. (2004). Calculating landscape surface area from digital elevation models. Wildl. Soc. Bull. 32, 829-839. doi: 10.2193/0091-7648(2004)032

Jetz, W., Rahbek, C., and Colwell, R. K. (2004). The coincidence of rarity and richness and the potential signature of history in centres of endemism. Ecol. Lett. 7, 1180-1191. doi: 10.1111/j.1461-0248.2004.00678.x

Kier, G., Kreft, H., Lee, T. M., Jetz, W., Ibisch, P. L., Nowicki, C., et al. (2009). A global assessment of endemism and species richness across island and mainland regions. Proc. Natl. Acad. Sci. U.S.A. 106, 9322-9327. doi: $10.1073 /$ pnas.0810306106

Kürschner, H., and Parolly, G. (2012). “The central Anatolian steppe," in Eurasian steppes. Ecological problems and livelihoods in a changing world, eds. M. J. A. Werger and M. A. van Staalduinen (Dordrecht: Springer), 149-171.

Kürschner, H., Parolly, G., and Raab-Straube, E. (1998). Phytosociological studies on high mountain plant communities of the Taurus Mountains (Turkey) 3. Snow-patch and meltwater communities. Feddes Repert. 109, 581-616.

Lamoreux, J. F., Morrison, J. C., Ricketts, T. H., Olson, D. M., Dinerstein, E., McKnight, M. W., et al. (2006). Global tests of biodiversity concordance and the importance of endemism. Nature 440, 212-214. doi: 10.1038/nature 04291

Linder, H. P. (2001). On areas of endemism, with an example from the African Restionaceae. Syst. Biol. 50, 892-912. doi: 10.1080/1063515017534 62867

Magyari, E. K., Chapman, J. C., Gaydarska, B., Marinova, E., Deli, T., Huntley, J. P., et al. (2008). The 'oriental' component of the Balkan flora: evidence of presence on the Thracian Plain during the Weichselian late-glacial. J. Biogeogr. 35, 865-883. doi: 10.1111/j.1365-2699.2007.01849.x 
Mahdavi, P., Akhani, H., and Van der Maarel, E. (2013). Species diversity and life-form patterns in steppe vegetation along a $3000 \mathrm{~m}$ altitudinal gradient in the Alborz Mountains, Iran. Folia Geobot. 48, 7-22. doi: 10.1007/s12224-012-9133-1

Major, J. (1988). "Endemism: a botanical perspective," in Analytical Biogeography, eds. A. A. Myers and P. S. Giller (London: Chapman and Hall), 117-146.

Margules, C. R., and Pressey, R. L. (2000). Systematic conservation planning. Nature 405, 243-253. doi: 10.1038/350 12251

Martínez-Hernández, F., Mendoza-Fernández, A. J., Pérez-García, F. J., Martínez-Nieto, M. I., Garrido-Becerra, J. A., Salmerón-Sánchez, E., et al. (2015). Areas of endemism as a conservation criterion for Iberian gypsophilous flora: a multi-scale test using the NDM/VNDM program. Plant Biosyst. 149, 483-493. doi: 10.1080/11263504.2015. 1040481

Mendoza-Fernández, A. J., Pérez-García, F. J., Martínez-Hernández, F., Salmerón-Sánchez, E., Medina-Cazorla, J. M., Garrido-Becerra, J. A., et al. (2015). Areas of endemism and threatened flora in a Mediterranean hotspot: southern Spain. J. Nat. Conserv. 23, 35-44. doi: 10.1016/j.jnc.2014. 08.001

Michaux, J. R., Libois, R., Paradis, E., and Filippucci, M. G. (2004). Phylogeographic history of the yellow-necked fieldmouse (Apodemus flavicollis) in Europe and in the Near and Middle East. Mol. Phylogenet. Evol. 32, 788-798. doi: 10.1016/j.ympev.2004.02.018

Mill, R. R. (1994). "Europe, Africa, Southwest Asia and the Middle East," in Centres of Plant Diversity: A Guide and Strategy for their Conservation, eds. S. D. Davis, V. H. Heywood and A. C. Hamilton. (Cambridge: IUCN Publications Unit), 293-348.

Mittermeier, R. A., Robles, G. P., Hoffman, M., Pilgrim, J., Brooks, T., Mittermeier, C. G., et al. (2005). Hotspots Revisited: Earth's Biologically Richest and Most Endangered Terrestrial Ecoregions. Washington, DC: Conservation International.

Morrone, J. J. (2008). Evolutionary Biogeography: An Integrative Approach With Case Studies. New York, NY: Columbia University Press.

Morrone, J. J., and Crisci, J. V. (1995). Historical biogeography Introduction to methods. Annu. Rev. Ecol. Syst. 26, 373-401. doi: 10.1146/annurev.es.26.110195.002105

Murray-Smith, C., Brummitt, N. A., Oliveira-Filho, A. T., Bachman, S., Moat, J., Lughadha, E. M.N., et al. (2009). Plant diversity hotspots in the Atlantic Coastal Forests of Brazil. Conser. Biol. 23, 151-163. doi: $10.1111 / j .1523-1739.2008 .01075 . x$

Myers, N., Mittermeier, R. A., Mittermeier, C. G., da Fonseca, G. A.B., and Kent, J. (2000). Biodiversity hotspots for conservation priorities. Nature 403, 853-858. doi: 10.1038/35002501.

Nelson, G., and Platnick, N. (1981). Systematics and Biogeography. New York, NY: Columbia Univ Press.

Noroozi, J., Pauli, H., Grabherr, G., and Breckle, S.-W. (2011). The subnivalnival vascular plant species of Iran: a unique high-mountain flora and its threat from climate warming. Biodivers. Conserv. 20, 1319-1338. doi: 10.1007/s10531-011-0029-9

Noroozi, J., Talebi, A., Doostmohammadi, M., Rumpf, S. B., Linder, H. P., and Schneeweiss, G. M. (2018). Hotspots within a global biodiversity hotspot areas of endemism are associated with high mountain ranges. Sci. Rep. 8:10345. doi: 10.1038/s41598-018-28504-9

Noroozi, J., Willner, W., Pauli, H., and Grabherr, G. (2014). Phytosociology and ecology of the high-alpine to subnival scree vegetation of $\mathrm{N}$ and NW Iran (Alborz and Azerbaijan Mts.). Appl. Vegetat. Sci. 17, 142-161. doi: 10.1111 /avsc. 12031

Orme, C. D. L., Davies, R. G., Burgess, M., Eigenbrod, F., Pickup, N., Olson, V. A., et al. (2005). Global hotspots of species richness are not congruent with endemism or threat. Nature 436, 1016-1019. doi: 10.1038/nature 03850

Parolly, G. (1998). Phytosociological studies on high mountain plant communities of the South Anatolian Taurus mountains 1. Scree Plant Commun. 28, 233-284. doi: 10.1127/phyto/28/1998/233

Parolly, G. (2004). The high mountain vegetation of Turkey - a state of the art report, including a first annotated conspectus of the major syntaxa. Turk. J. Botany 28, 39-63.
Parolly, G. (2015). "The high mountain flora and vegetation of the Western and Central Taurus Mts. (Turkey) in the times of climate change," in Climate Change Impacts on High-Altitude Ecosystems, eds. M. Öztürk, K. R. Hakeem, I. Faridah-Hanum, R. Efe. (Basel: Springer), 99-133.

Parolly, G., Nordt, B., Bleeker, W., and Mummenhoff, K. (2010). Heldreichia Boiss. (Brassicaceae) revisited: a morphological and molecular study. Taxon 59, 187-202. doi: 10.2307/27757062

Possingham, H. P., and Wilson, K. A. (2005). Biodiversity: turning up the heat on hotspots. Nature 436, 919-920. doi: 10.1038/4 $36919 \mathrm{a}$

Qi, Y., and Yang, Y. (1999). Topographic effect on spatial variation of plant diversity in California. Geograp. Inform. Sci. 5, 39-46.

R, Core Team (2015). R: A Language and Environment for Statistical Computing. Vienna: R Foundation for Statistical Computing.

Rahbek, C. (1997). The relationship among area, elevation, and regional species richness in neotropical birds. Am. Nat. 149, 875-902. doi: 10.1086/286028

Rivas-Martínez, S., Asensi, A., Díez-Garretas, B., Molero, J., and Valle, F. (1997). Biogeographical synthesis of Andalusia (southern Spain). J. Biogeogr. 24, 915-928. doi: 10.1046/j.1365-2699.1997.00149.x

Rokas, A., Atkinson, R. J., Webster, L., Csóka, G., and Stone, G. N. (2003). Out of Anatolia: longitudinal gradients in genetic diversity support an eastern origin for a circum-Mediterranean oak gallwasp Andricus quercustozae. Mol. Ecol. 12, 2153-2174. doi: 10.1046/j.1365-294X.2003.01894.x

Runemark, H. (1971). "Distribution patterns in the Aegen," in Plant life of SouthWest Asia, eds P. H. Davis, P. C. Harper and I. C. Hedge (Edinburgh: The Botanical Society of Edinburgh), 3-12.

Sales, F., and Hedge, I. C. (2013). Generic endemism in South-West Asia: an overview. Rostaniha 14, 22-35. doi: 10.22092/botany.2013.101306

Scherrer, D., and Körner, C. (2010). Infra-red thermometry of alpine landscapes challenges climatic warming projections. Global Change Biol. 16, 2602-2613. doi: $10.1111 / \mathrm{j} .1365-2486.2009 .02122 . \mathrm{x}$

Scherrer, D., and Körner, C. (2011). Topographically controlled thermal-habitat differentiation buffers alpine plant diversity against climate warming. J. Biogeogr. 38, 406-416. doi: 10.1111/j.1365-2699.2010.02407.x

Senkul, Ç., and Kaya, S. (2017). Türkiye endemik bitkilerinin cografi dagilişi. Turkish Geograp. Rev. 69, 109-120. doi: 10.17211/tcd.322515

Spehn, E. M., Rudmann-Maurer, K., and Körner, C. (2011). Mountain biodiversity. Plant Ecol. Diver. 4, 301-302. doi: 10.1080/17550874.2012.6 98660

Steinbauer, M. J., Dolos, K., Field, R., Reineking, B., and Beierkuhnlein, C. (2013). Re-evaluating the general dynamic theory of oceanic island biogeography. Front. Biogeogr. 5, 185-194. doi: 10.21425/F55319669

Steinbauer, M. J., Field, R., Grytnes, J.-A., Trigas, P., Ah-Peng, C., Attorre, F., et al. (2016). Topography-driven isolation, speciation and a global increase of endemism with elevation. Global Ecol. Biogeograp. 25, 1097-1107. doi: $10.1111 /$ geb.12469

Szumik, C. A., Cuezzo, F., Goloboff, P. A., and Chalup, A. E. (2002). An optimality criterion to determine areas of endemism. Syst. Biol. 51, 806-816. doi: $10.1080 / 10635150290102483$

Szumik, C., and Goloboff, P. A. (2004). Areas of endemism: an improved optimality criterion. Syst. Biol. 53, 968-977. doi: 10.1080/10635150490 888859

Szumik, C. A., and Goloboff, P. A. (2015). Higher taxa and the identification of areas of endemism. Cladistics 31, 568-572. doi: 10.1111/cla.12112

Takhtajan, A. (1986). Floristic Regions of the World. Berkeley: Univeristy of California Press.

Türe, C., and Böcük, H. (2010). Distribution patterns of threatened endemic plants in Turkey: a quantitative approach for conservation. J. Nat. Conser. 18, 296-303. doi: 10.1016/j.jnc.2010.01.002.

Ünal, M., and Behçet, L. (2007). Flora of Pirreflit Mountain (Van, Turkey). Turk. J. Botany 31, 193-223.

Vanderplank, S. E., Moreira-Munoz, A., Hobohm, C., Pils, G., Noroozi, J., Clark, V. R., et al. (2014). "Endemism in mainland regions - case studies," in Endemism in vascular plants, ed. C. Hobohm (Dordrecht: Springer), 205-308.

Weirauch, C., Seltmann, K. C., Schuh, R. T., Schwartz, M. D., Johnson, C., Feist, M. A., et al. (2017). Areas of endemism in the Nearctic: a case study of 1339 species of Miridae (Insecta: Hemiptera) and their plant hosts. Cladistics 33, 279-294. doi: $10.1111 /$ cla.12169 
Williams, P. H. (2000). Some properties of rarity scores for sitequality assessment. Br. J. Entomol. Natur. Hist. 13, 73-86.

Zhang, D.-C., Ye, J.-X., and Sun, H. (2016). Quantitative approaches to identify floristic units and centres of species endemism in the Qinghai-Tibetan Plateau, south-western China. J. Biogeogr. 43, 2465-2476. doi: 10.1111/jbi. 12819

Zohary, M. (1971). "The phytogeographical foundation of the Middle East," in Plant life of south-west Asia, eds. P. H. Davis, H. P. C. and I. C. Hedge (Edinburgh: Botanical Society of Edinburgh), 43-52.

Zohary, M. (1973). Geobotanical Foundations of the Middle East 2. Stuttgart: Gustav Fischer.
Conflict of Interest Statement: The authors declare that the research was conducted in the absence of any commercial or financial relationships that could be construed as a potential conflict of interest.

Copyright (c) 2019 Noroozi, Zare, Sherafati, Mahmoodi, Moser, Asgarpour and Schneeweiss. This is an open-access article distributed under the terms of the Creative Commons Attribution License (CC BY). The use, distribution or reproduction in other forums is permitted, provided the original author(s) and the copyright owner(s) are credited and that the original publication in this journal is cited, in accordance with accepted academic practice. No use, distribution or reproduction is permitted which does not comply with these terms. 